\title{
Sustainability status of agroforestry systems in Timor Island, Indonesia
}

\author{
Eko Pujiono ${ }^{1 \varpi}$, S Agung Sri Raharjo ${ }^{2}$, Gerson N Njurumana ${ }^{1}$, Budiyanto D Prasetyo ${ }^{3}$ and Heny Riana wati ${ }^{1}$ \\ ${ }^{1}$ Forestry and Environment Research and Development Institute, Kupang, Indonesia \\ ${ }^{2}$ Watershed Management Technology Centre, Surakarta, Indonesia \\ ${ }^{3}$ Centre for Research and Development of Socio Economic Policy and Climate Change, Bogor, Indonesia
}

\begin{abstract}
Agroforestry systems can be considered as sustainability concept. They are able to provide ecological, economical and sociological benefit. In order to help policy makers and stakeholder decide what action should be taken to make agroforestry sustainable, the identification of the sustainability status is needed. This study aimed to evaluate the sustainability status of agroforestry systems in Timor Island, one of the islands in Nusa Tenggara Timur Province, eastern Indonesia. The data was collected through combination of field observation and interviews with 38 respondents with purposively selected in three dominant agroforestry systems, namely: mixed-garden, mamar, traditional agroforestry and silvopasture. Multidimensional Scaling approach was used to analyse the sustainability status of agroforestry systems based on five dimensions (ecology, economy, social, institutional and technology) as well as 26 attributes. The attribute valuation was in ordinal scale based on sustainable criteria of each dimension. The criteria were ranked from 0 (the lowest) to 3 (the highest). The assessment of sustainability status was classified into: not sustainable $(0-25 \%)$, less sustainable $(25-50 \%)$, moderate sustainable (50-75\%) and good sustainable (75$100 \%)$. The result revealed that the sustainability of all agroforestry systems were in moderate sustainable. This study found that, only 15 out of 26 attributes were categorized as sensitive attributes. Such data and information are important for the agroforestry farmer or other related stakeholder for improving appropriate strategies or action in sustainable agroforestry management.
\end{abstract}

\section{Introduction}

The combination of dry climatic conditions, lack of water supply, thin soil solum and nutrient-poor soil conditions and low technology inputs, has made the Province of Nusa Tenggara Timur (NTT) often faced with the problem of low land productivity [1] which leads to poverty and food insecurity. The World Food Organization, World Food Program (WFP) Indonesia and the Ministry of Health, reported that NTT is one of the four provinces in Indonesia that has the highest poverty rate with 25.26 percent of the population living below the nationalpoverty line in 2020 [2]. In 2015, the NTT Food Security Agency stated that, over 81 sub-districts (27\% of totalsub-district) in NTT were hit by drought so that they were threatened with food insecurity [3].

Optimizing of agroforestry function to support food security is one of the efforts to address the problems of poverty and food insecurity. This effort is fea sible considering that NTT has long been known to have a high diversity of agroforestry systems [1]. The agroforestry of Mamar in Timor Island [4], [5], [6] and Kaliwu in Sumba Island [7] can be classified as traditional agroforestry, while. In addition to traditional agroforestry, it were also found other introduced agroforestry systems in Amarasi (Timor) in the 1930s, in Sikka (Flores) in the 1960s and East Sumba in the 1980s [1]. More recently, there were some concepts of a groforestry which implemented in NTT, e.g. silvopa sture, silvofishery and mixed-garden/mixed-farming [8]. The variety of a groforestry systems is probably due to the diversity of cultural, social, economic and geographical conditions that comprise many islands.

${ }^{\square}$ Corresponding author: ekopujiono78@gmail.com 
Agroforestry is a land management with sustainability concept which can be framed as a balance between economic, ecological and social interests [9]. Globally, agroforestry can contribute to the Sustainable Development Goals (SDGs) - a global action plan to action to end poverty, protect the planet and ensure that all people enjoy peace and prosperity by 2030 , especially on poverty reduction (SDG 1), hunger alleviation (SDG 2)climate action (SDG 13), biodiversity conservation and sustainable land management (SDG 15) [10]. In locallevel, numerous studies have been conducted in NTT and these studies were separately analyzed ecological, economy and socio-cultural a spects of a groforestry systems [8],[11]. Unfortunately, study at the local scope (NTT Province) linking agroforestry systems with the concept of sustainability which includes several a spects is still limited.

In order to help policy makers and stakeholder decide what action should be taken to make agroforestry sustainable, the identification of the sustainability status is needed. One of the tool to evaluate the sustainability is Multidimensional scaling (MDS) which firstly employed by [12] and known as Rapid Appra sial for Fishery (Rapfish). Further, MDS a pproach was developed for various fields such a s forestry - RapPforest [13], agriculture - RapLandUse [14], and community forestry - Rap CF [15]. Although sustainability study have been separately carried out in the fisheries, agriculture and forestry sectors, an evaluation of the sustainability of agroforestry systems that combines these sectors has never been carried out. Sustainability status of agroforestry is important for: (1) evaluating susta ina bility trade-offs, (2) finding the barrier dimensions/a spects in a groforestry management, (3) encoura ging broad participation by stakeholder, (4) arranging the improvement (planning, strategies, etc.) to achieve the agroforestry management goals. For those reason, this study aimed to evaluate the sustainability status of agroforestry systems $(\operatorname{Rap} A F)$ in Timor Island, NTT Province, Indonesia.

\section{Methods}

\subsection{Study area}

Timor Island is one of main islands in Nusa Tenggara Timur Province, eastern Indonesia, and extends within coordinates $124^{\circ} 5^{\prime} 25^{\prime \prime}$ to $124^{\circ} 21^{\prime} 44^{\prime \prime} \mathrm{E}$ and $9^{\circ} 26^{\prime} 57^{\prime \prime}$ to $9^{\circ} 41^{\prime} 28^{\prime \prime} \mathrm{S}$ (Figure 1). Timor Island covers an area of approximately 30 thousand $\mathrm{km}^{2}$ which is divided into two almost equalparts, the West Timor region (Indonesia) and the East Timor region (Timor Leste). Administratively, Timor Island is divided into several districts, some of whose territories are directly adjacent to the Democratic Republic of Timor Leste (Figure 1). The climate of the Timor Island area is tropical with two major seasons, i.e., the dry season (April to October) and the rainy season (November to March). The avera ge temperature is $27^{\circ} \mathrm{C}$ and there is a variation since in lower elevation (lowland and coastal region) temperature get as $32^{\circ} \mathrm{C}$ while in the high mountains it may rela tively cool, about $23^{\circ} \mathrm{C}$ (mountain region). The average annual precipitation is approxima tely 1600 millimeters which occurs between November to March, with little to no precipitation during the remaining months[16]. Slope class is dominated by moderately slope, with variations gently slop and nearly level in coastalareas and steep slopes in hilly / mounta inous areas and the peak of Mount Mutis with an altitude of $2,427 \mathrm{~m}$ is identified as the highest place in Timor Island. Land cover on the island of Timor is dominated by secondary forest (28\%); mixed dry land agriculture $(21 \%)$, shrubs $(14 \%)$ and other remaining land cover are savanna, primary forest, residential, rice fields and water bodies).

Among these existing land cover classes, agroforestry is generally found in the mixed dry land agricultural land cover class. Of the several a groforestry systems, there are three main agroforestry systems in Timor, namely mix edgarden, mamar and silvopasture. Mixed-gardens is commonly found in high or medium areas, with a mixed cropping system of a gricultural, forestry and fruit crops. Mamar can be found in the lowlands with, dominated by tree planting for water conservation purposes (Ficus sp), betel nut for socio-cultural needs and sea sonal, fruits \& other woody plants for economic purposes. For the silvopasture system, forestry crops, fodder crops and seasonalcrops are planted together on the same land. General condition of three a groforestry systems is presented in Table 1. 


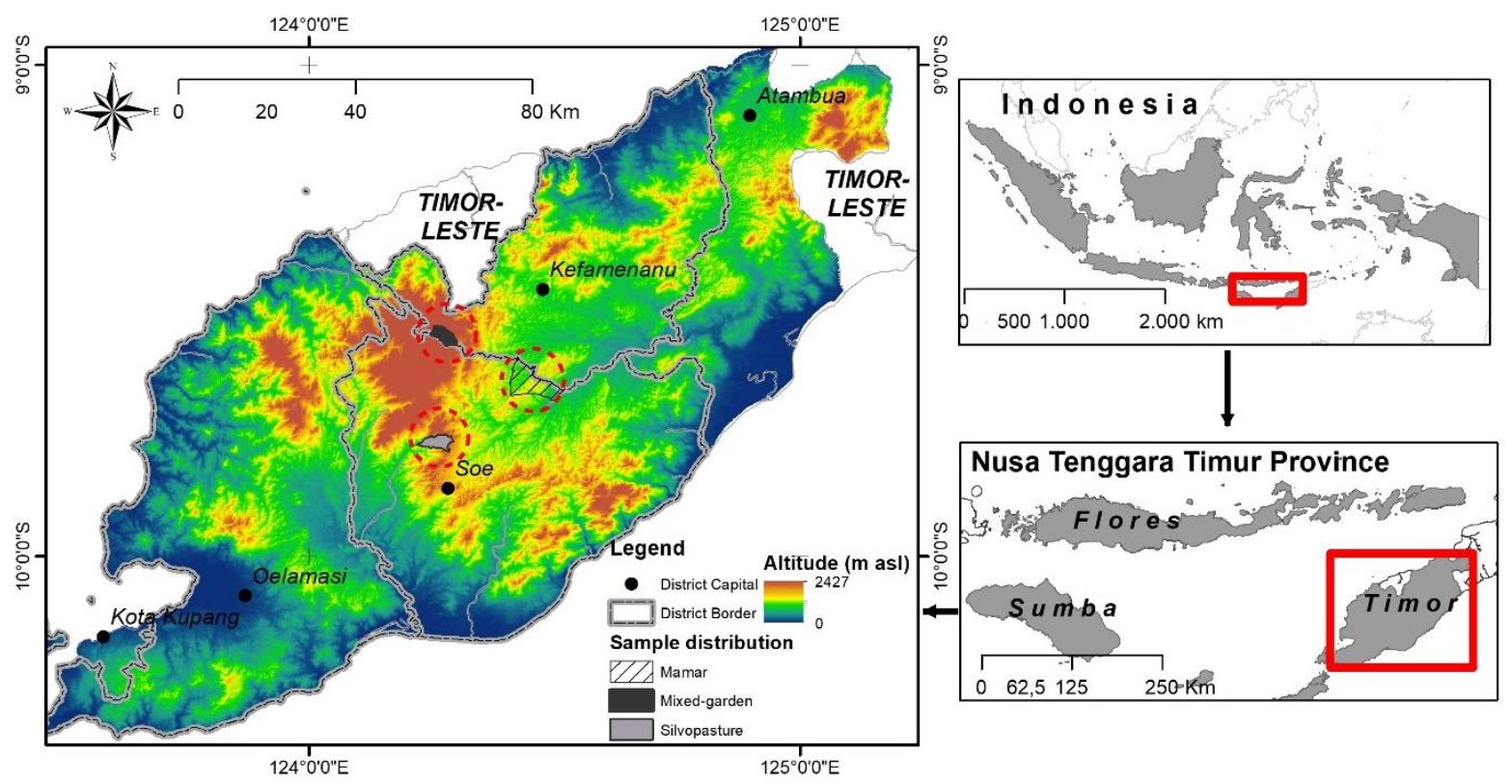

Fig. 1. Study area - Timor Island, Nusa Tenggara Province, Indonesia, presented on Digital Elevation Model (DEM) Imagery, dotted red circle indicated sample distribution of agroforestry systems.

Table 1. Overview of three agroforestry systems in Timor Island

\begin{tabular}{|c|c|c|c|c|}
\hline $\begin{array}{l}\text { Agroforestry } \\
\text { Systems }\end{array}$ & Products & Purpose & General condition & Partner \\
\hline $\begin{array}{l}\text { Mixed-garden } \\
( \pm 700 \mathrm{~m} \text { asl })\end{array}$ & $\begin{array}{l}\text { food (nut, corn, rice); tree } \\
\text { (white teak /gmelina, } \\
\text { mahogany); } \\
\text { fruits (orange, pineapple) }\end{array}$ & $\begin{array}{l}\text { Subsistent; } \\
\text { commercial }\end{array}$ & $\begin{array}{l}\text { Cropping pattern is } \\
\text { dominated by food crop, } \\
\text { limited tree (only plant } \\
\text { along border) }\end{array}$ & $\begin{array}{l}\text { Non-Government } \\
\text { Organization-Yayasan } \\
\text { Mitra Tani Mandiri- } \\
\text { YMTM (since } 1999 \text { - now) }\end{array}$ \\
\hline $\begin{array}{l}\text { Mamar }( \pm 800 \\
\text { m asl })\end{array}$ & $\begin{array}{l}\text { food (taro/ talas); } \\
\text { (goldfish); trees (mahogany, } \\
\text { banyan tree-Ficus/ beringin); } \\
\text { fruits (mangoes, coconut, } \\
\text { areca nut/ pinang); }\end{array}$ & $\begin{array}{l}\text { Subsistent; } \\
\text { commercial; } \\
\text { water } \\
\text { conservation }\end{array}$ & $\begin{array}{l}\text { Cropping pattern is } \\
\text { dominated by tree crop; } \\
\text { water conservation } \\
\text { oriented }\end{array}$ & - \\
\hline $\begin{array}{l}\text { Silvopasture } \\
( \pm 1000 \mathrm{mdpl})\end{array}$ & $\begin{array}{l}\text { tree (blackwood cassia/ } \\
\text { johar, mahogany, } \\
\text { hazelnut/kemiri); forage } \\
\text { (king grass) }\end{array}$ & $\begin{array}{l}\text { Subsistent; } \\
\text { commercial }\end{array}$ & $\begin{array}{l}\text { Cropping pattern is } \\
\text { dominated by forage, } \\
\text { limited tree (only plant } \\
\text { along border) }\end{array}$ & $\begin{array}{l}\text { Forest Services of TTS \& } \\
\text { Japan Overseas Forestry } \\
\text { Consultant Associates } \\
\text { (JOFCA) }\end{array}$ \\
\hline
\end{tabular}

\subsection{Data}

Data were collected through combination of literature study, field observation and interview. For literature review, previous studies and other publications related to agroforestry research and MDS analysis were collected. In field observations, three locations (Figure 1), namely: (1) mixed-garden in Noepesu Village, Timor Tengah Utara (TTU) District, mamar in Loli Village, Timor Tengah Selatan (TTS) District and silvopasture system in Oelbubuk Village, TTS District, were purposively selected based on their agroforestry types and altitude. The data was also collected through interviews with the farmers of agroforestry systems. The a spects/parameters which asked in interview were demography (age and gender), ecology (land productivity, soil conservation, land cover, vegetation density, and land cultivation area), economy (agroforestry products, product market, contribution of a groforestry income, contribution of non-agroforestry income, poverty level, family member of dependents, adaptation on agroforestry commodities demand), social (education level, perception on soil conservation, perception on agroforestry activities, participation in a groforestry), institution(farmers groups activity, farmers accompaniment, knowledge of traditional rules, decision making process, and leadership), and also the use of technology (land preparation, planting, plant maintenance, 
harvesting, postharvest processing, and soil conservation). The respondents of each agroforestry systems were determined using snowball method. The total numbers of respondents were 38 farmers. The average aged of respondents aged 45 years old, the dominant education was elementary school, the average number of dependents was 4 (four) people, and the average cultivated land was $0.30 \mathrm{ha} /$ farmer.

\subsection{Analysis}

MDS is a method of multivariate statistical analysis that determines the position of a concept based on similarity or dissimilarity to another principle or concept [13]. MDS is a data analysis technique which displays conceptual similarity in the form of geometric images based on the Euclidean distance between concepts, ba sed on questionnaire responses [13]. The MDS analysis was performed by using Rapid appraisal for agroforestry (RapAF) which was developed from Rapfish [12] and Rapid appraisal for community forestry (RapCF) [15]. There were five dimensions (ecology, economic, social, institutional, technology dimension) and 26 attributes used in this research. The attribute valuation was in ordinal scale based on the sustainability criteria of each dimension (Appendix 1). The criteria were ranked from 0 (the lowest) to 3 (the highest). The assessment of sustainability index was categorised into four groups (Kavanagh \& Pitcher, 2004), na mely: not sustainable ( $0-25 \%)$, less susta inable $(>25-50 \%)$, moderate sustainable ( $>50$ $75 \%)$ and good sustainable ( $>75-100 \%)$. The level of susta ina bility dimensions was displayed simultaneously by using kite dia grams. The evaluation of susta inability index was followed up by the determination of the leverage factors and Monte Carlo analysis. The levera ge analysis was used to find the sensitive sustainability attributes based on root mean square (RMS) value [16]. The higher the RMS value, the greater the attribute effect on the level of sustainability. Attributes greater than the median on each dimensions are identified as sensitive attributes. Monte Carlo analysis was used to determine the random error of all dimensions. The results of Monte Carlo analysis was compared to those of MDS analysis, as a result is $95 \%$ degree of confidence, hence it could be determined that the difference value between the results was approximately $5 \%$. If the difference was $<5 \%$, the MDS result was sufficient to predict the susta inability of agroforestry systems. The final stage was the goodness of fit using S-stress value by calculating the $\mathrm{S}$ value and coefficient determination $\left(\mathrm{R}^{2}\right)$. The lower the $\mathrm{S}$, the higher the goodness of fit. A good model contain $\mathrm{S}$ value less than $0.25(\mathrm{~S}<0.25)$ and rela tively better fitting model have an $\mathrm{R}^{2}$ value that approach to 1 [16].

\section{Results and discussions}

\subsection{Sustainability status of agroforestry systems}

The result revealed that the susta inability of three a groforestry systems were in moderate sustainable with the average of sustainability index for all dimensions were $54 \%$ for mixed-garden; $52 \%$ for mamar and $51 \%$ for silvopasture. Based on the results, the typology dimension of mixed-garden and silvopa sture almost similar (Figure 1). In mamar types, the ecology dimension were classified as good susta inable, but for the institutional dimension they ha ve lowest value of sustainable status. It could be interpreted that a groforestry management in Timor Island were fairly good.

Considering that no research has been found regarding the sustainability status of agroforestry, results will be compared to the sustainability status of other sectors which are element of agroforestry, namely the agriculture, forestry and livestock sectors. Regarding to susta inability status of a griculture, previous study by using 5 (five) similar dimensions with 43 attributes reported that sustainability status of paddy field in Karawang was categorized as less susta inable [14]. Further, in forestry sector, by using 5 dimensions with 18 attribute found that the sustainability status of privately managed forest in Bogor was classified as moderate susta inable [13]. For livestock sectors, analysis MDS using 5 similar dimensions indicated that the susta inability of beef cattle fattening was categorized as less sustainable. Although using almost the similar dimensions and attributes, the differences in study sites, e.g. the biophysical conditions of the land and the socio-economic conditions of the community may cause differences in the level of sustainability 


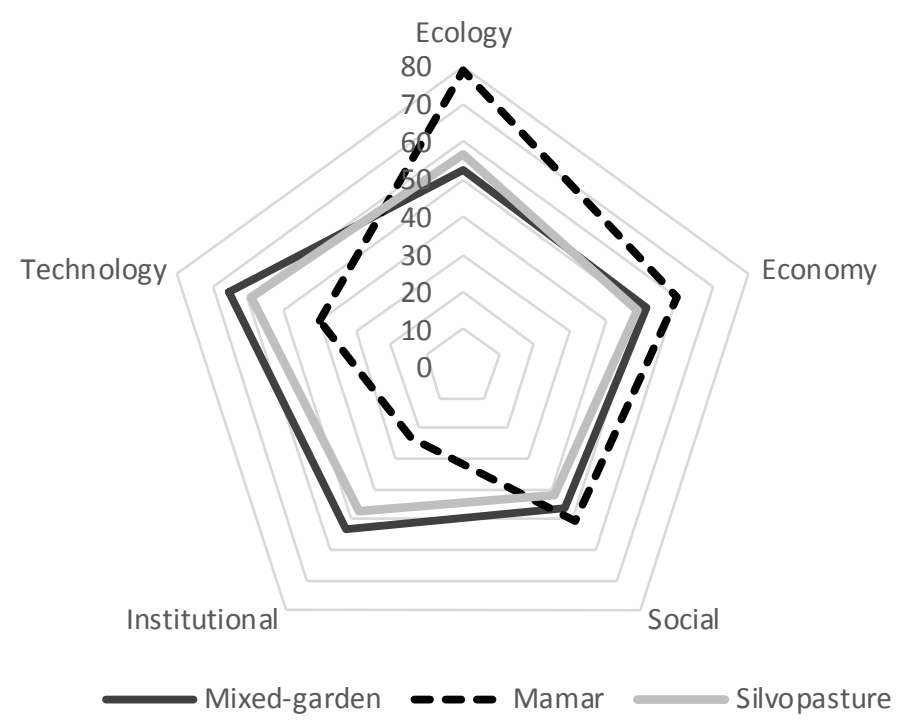

Fig. 2. Kites diagram of the three agroforestry systems in Timor Island

\subsection{Sensitive attributes of agroforestry systems sustainability}

The leverage analysis on three agroforestry systems indicated that only 15 out of 26 attributes were categorized as sensitive attribute. Result revealed that 5 (five) attributes of ecological dimension, 4 (four) attributes of economy, one attribute of social, one attribute of institutional, and 4 (four) attributes of technology dimension (Figure 3). Those attributes should be prioritized to increase the sustainability status/ level of agrof orestry system.

In ecological dimension, erosion, the use of soil conservation, land cover, vegetation diversity and land cultivation are considered as sensitive attribute to agroforestry sustainability. Previous research reported that soil erosion, land cover and vegetation diversity were inter-correlated, in which, increasing vegetation diversity will increase land cover and reduce soil erosion [15]. Vegetation diversity in the agroforestry is an effort to avoid single commodity -based production failures while at the same time creating a balance between the environment and food security (security foods). Regarding to vegetation diversity, previous studies also reported that mamar is the agroforestry system with the highest species diversity - consisting 79 species [11].

In economic dimension, product, contribution of a groforestry and non-agroforestry income and poverty level are categorized as sensitive attributes to a groforestry susta inability. Agroforestry systems that contributes $60-95 \%$ of the totalincome, is identified as sensitive attribute. Mixed-garden gives the highest contribution to total income, followed by mamar and silvopasture contributions [8].

In the social and institutional dimensions, only one sensitive attribute was found, namely the level of education and knowledge of institutiona1/traditional rules, respectively. In Timor community, there is a prohibition on carrying out activities in certain locations which are accompanied by customary sanctions if anyone violates them. Timor people calls the term customary law with the name of Вапи. The existence of Banu makes this knowledge as sensitive attribute in agroforestry susta inability a ssessment.

For the technological dimension, there are four sensitive attributes, namely: land preparation, planting, harvesting and post-harvesting processes. In genera 1 , land clearing is still carried out by slash and burn method, while planting is still using local seeds. Furthermore, harvesting is carried out irregularly (cut when needed) and activities to provide added value to the harvest have not been found.

In addition to those aforementioned sensitive attributes, it is also found that several attributes were statistically considered less sensitive, or whose contribution to susta inability index is smaller than sensitive attributes. In economic dimension, number of agroforestry product and adaptation to demand are inter-correlated and related to market characteristics. Based on previous study [8], market characteristics in the study area are dominated by demand for food products and have not expanded to other product va ria tions, so it makes sense that number of a groforestry product and a daptation to demand variables are considered less sensitive attributes. Regarding social dimension, indicators of perception and participation in agroforestry activities are considered less sensitive when compared to indicators of education level. Community/farmers perceived that their daily a gricultural activities are part of their participation in agroforestry activities, so it is appropriate that perception and participation variables are considered as less sensitive variables in the assessment of a groforestry sustainability index. In the institutional dimension, existence of farmer groups, decision making and leadership in farmer groups variables are considered as less sensitive attributes because 
the community or farmers are still accustomed to working alone without formal institutions. They also seem to be more obedient to traditional institutions with their customary rules than to formal institutions and their rules [8]. In technological dimension, va riabel of intensive plant maintenance have not become a priority for the community. They only focused on planting, minimalmaintenance and harvesting, so it is make sense that plant ma intenance variable to be a less sensitive variable when compared to planting or harvesting activities.

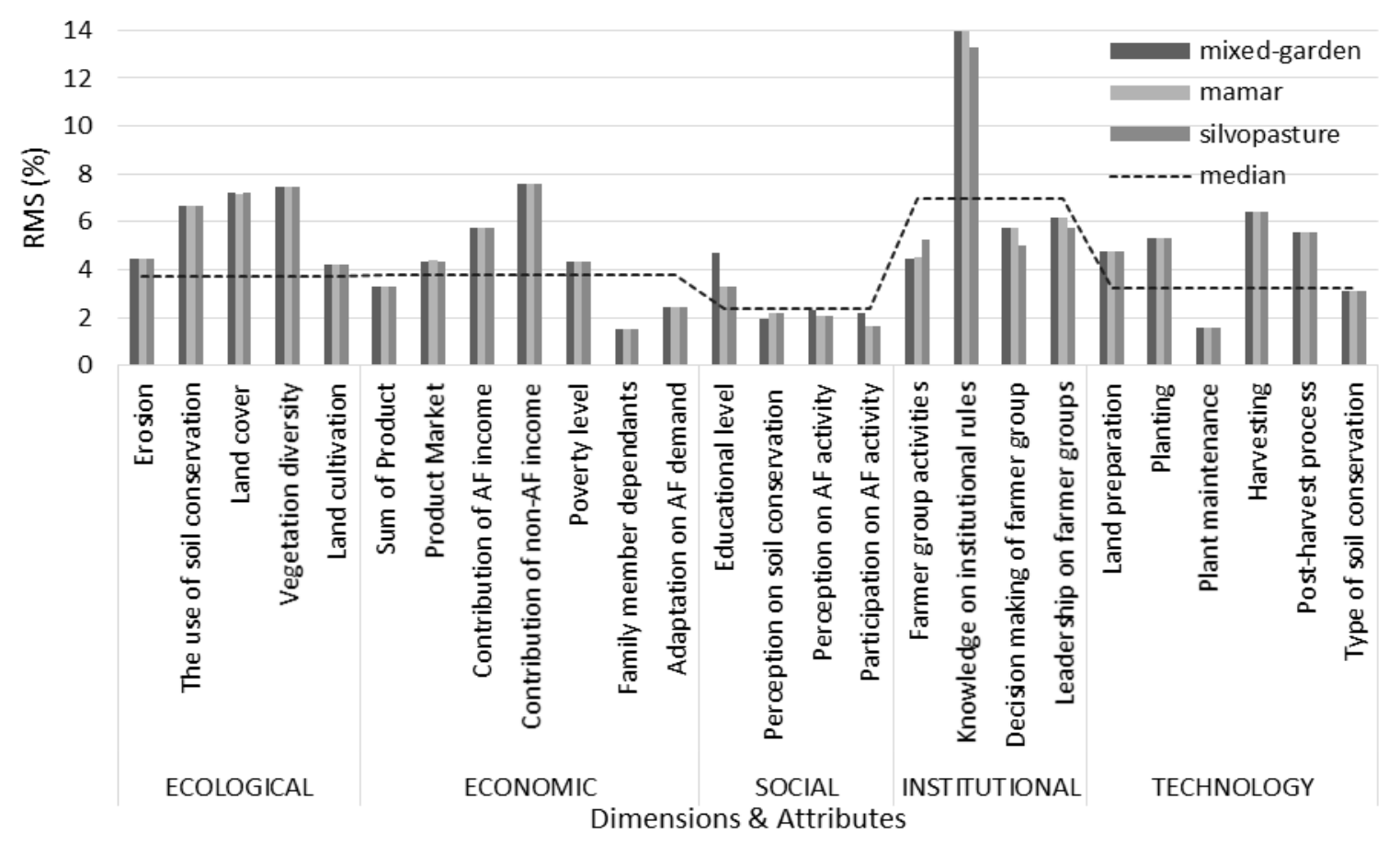

Fig. 3. Column bar displaying the sensitive attributes of agroforestry sustainability (attributes which have RMS value greater than median value of RMS in each dimensions - indicated by dashed line)

Comparison between MDS analysis results and the monte carlo analysis showed a small difference in value, or below $5 \%$ (Figure 4). The small difference in value indicates that the effect of errors on scoring for each attribute, data entry errors and proceduralerrors that can affect the stability of the MDS a nalysis is relatively small. In other words, the confidence level of the multidimensional susta inability index on the dimensional index is more than $95 \%$. This means that the MDS model is sufficient to predict the susta inability of the agroforestry systems in the Timor Island. 


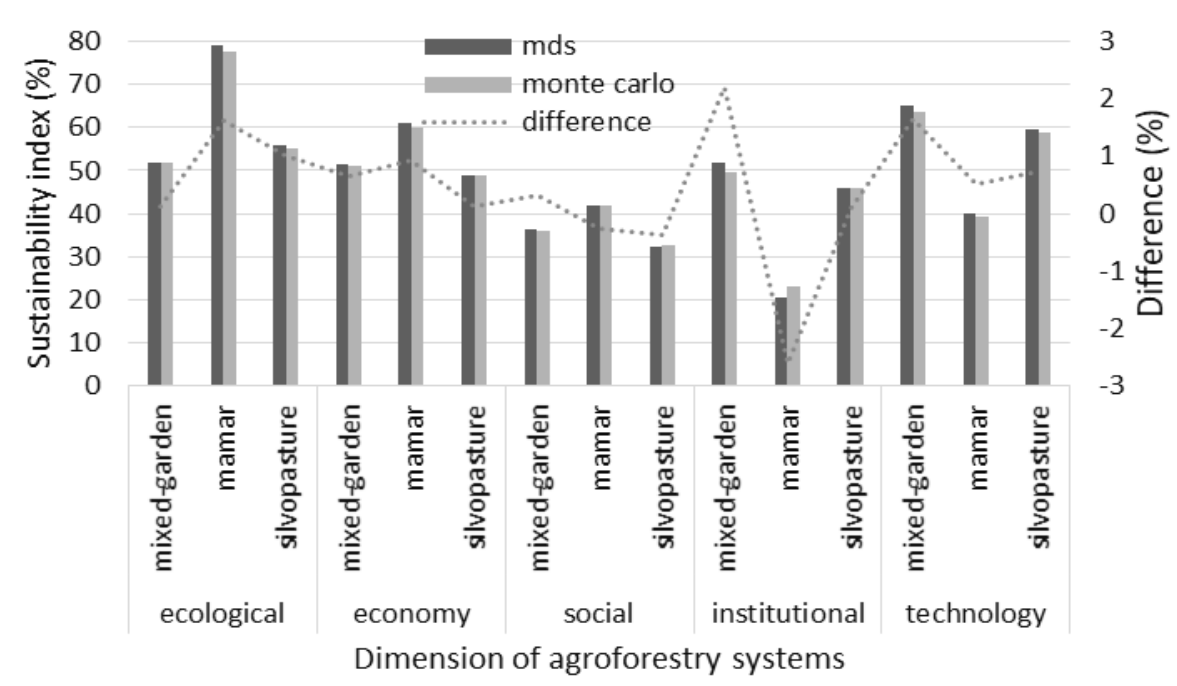

Fig. . Column bar and dashed line displaying the difference between MDS and Monte Carlo analysis of the three agroforestry systems in Timor Island

The coefficient of determination $\left(\mathrm{R}^{2}\right)$ obtained from the $R a p A F$ analysis is greater than $90 \%$ or even close to $100 \%$ (Figure 5). This value indicates that the model for estimating the sustainability status / index is good and adequate to use. $\mathrm{R}^{2}$ and $\mathrm{S}$ values that are sma ller than 0.25 indicate that the model obta ined ha s high accuracy.

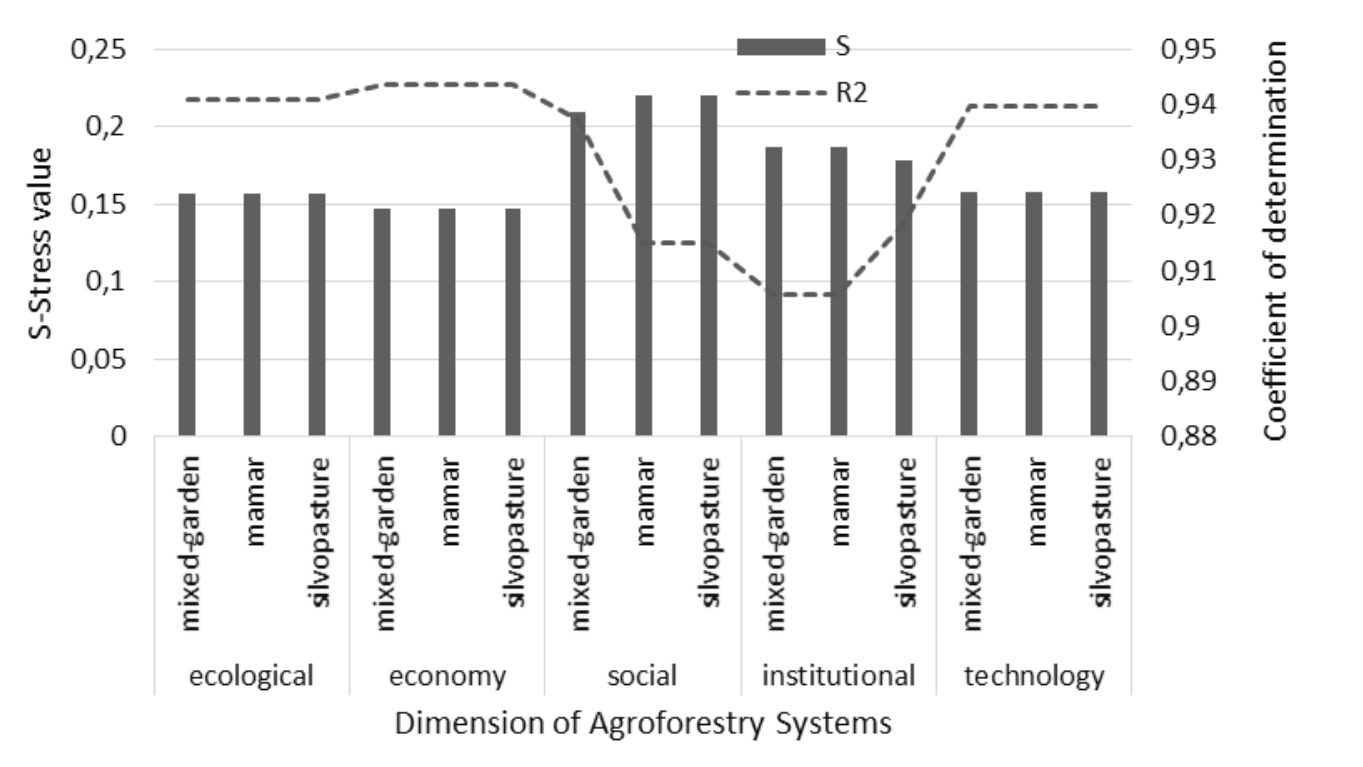

Fig. 5. Column bar and dashed line describing S-stress value and coefficient of determination MDS analysis of the three agroforestry systems in Timor Island

\subsection{General findings - comparison of three agroforestry systems}

The comparison of the three agroforestry systems analyzed found that there are similarities in socio-economic and cultural aspects and differences, especially in technical and ecological aspects. On the social aspect, farmers who practice these three agroforestry systems generally have basic education (elementary school). This has an impact on traditiona1/ simple land management, characterized by: land clearing by slash-and-burn, planting with local seeds/seeds, minimal ma intenance, and pays less attention to the added value of the harvested commodity. Regarding the economic aspect, income contribution from these agroforestry systems to total income is relatively high (around $80 \%)$ if compare to income contribution from non-agroforestry activities [8]. In culture aspects, at those three agroforestry sites, people still believe in traditional institutions and follow their customary regulations. 
What about the differences between the three agroforestry systems? The first difference is seen from tech nical aspect - purpose of a groforestry systems. In mixed-garden system, farmers are more focused on optimizing food crop yields, the mamar system is water conservation oriented, while the silvopasture system focuses on fulfilling animal fodder. The purpose of the agroforestry system then affects the second difference, namely cropping pattern. Mixed garden and silvopa sturalsystems are generally dominated by farmer-made engineering, where farmers prioritize food crops, rice, maize, beans ( mixed garden system) and animal fodder crops (silvopa sture system). In both systems, the existence of tree crops are only additional products (not main product) and generally planted on land boundaries. In opposite, the mamar system is a natural system with slight modifications from farmers, where the site is dominated by tree species for water conservation, such as banyan, and other trees. In addition, in most of the mamar sites, areca nut species were commonly found, which the community used for their daily needs (chewing betel nut) as well as for traditional events of Timorese people. Related to technical aspects (soil and water conservation practices), in accordance with typology of location, in mixed-garden system and silvopasture systems (representation of mountainous/hill landscapes typology), terrace-building practices have been found, which are aimed at reducing run - off/ erosion. While mamar system which represent landscape typology of valleys/around bodies of water, conservation practices are carried out by planting water-storing tree species.

\subsection{Sustainability improvement strategies}

In particular, related to key findings-the sensitive attributes of agroforestry sustainability, some proposed strategies are: (1) maintaining ecological conditions, in particular maintaining tree cover and preventing soil erosion, (2) improving economic conditions by improving market access and reduce poverty, (3) improving the quality and qua lity of education to be more technologically literate, (4) maintain the existence of customary institutions and their customary rules, and (5) optimize agroforestry land management technology by improving land preparation, using superior seeds and adding value to the agroforestry products produced.

In general, based on the field observation, there are some constra ints in a groforestry management, namely, limited financialcapital, limited technological inputs, weak market access and product diversification. Previous studies which are relevant to this study, reported that there are some important issues that must be considered in agroforestry development, namely: sea sonal patterns, land conditions, product diversification, and customary institutions [1].

The above key findings, constraints and issues in agroforestry development can be overcome with good cooperation between the government, private sector and farmers. The government can play a role in optimizing technical guidance for farmers and ensuring market availability. The private sector can be involved as invest ors or partners for capital-intensive agroforestry enterprises. Farming communities as the main actors must maintain enthusiasm and motivation to work and strengthen their farmer group institutions.

\section{Conclusion and recommendations}

In this study, a multidimensional scaling (MDS) approach can be used as an alternative method for evaluating the susta inability status of a groforestry systems in Timor. By using 26 attributes of 5 dimensions, this MDS exhibited a good performance in estimating the status of a gro forestry susta inability. Our finding emphasized that the sustainability status of all agroforestry systems, i.e. mixed-garden, mamar and silvopasture were in moderate sustainable. Even this study could provide good insights into quantitative information of recent sustainability status of three agroforestry systems, it could not describe the past or future sustainability status of these three and other agroforestry systems. Therefore, developing other types of time series sustainability status with a greater number of other agroforestry systems, is needed.

In relation to sensitive attributes to agroforestry sustainability, we found that, only 15 out of 26 attributes were categorized as sensitive attributes, some of which are soil erosion, contribution of agroforestry income, educational level, knowledge on institutiona1/ traditional rules and other technical aspects. Those attributes should be prioritized to increase the susta inability status/ level of agroforestry system.

Overall, this study demonstrated the benefits of MDS as tools in estimating sustainability status of agroforestry systems and determining sensitive attribute to agroforestry susta inability. Such data and information are important for the agroforestry farmer or other related stakeholder for improving appropriate strategies or action in sustainable agroforestry management. 


\begin{tabular}{|c|c|c|}
\hline Dimension/ & Description & Criteria \& Score \\
\hline \multicolumn{3}{|l|}{ ECOLOGICAL } \\
\hline Erosion & soil erosion & high (0); moderate(1); low (2); very low (3) \\
\hline $\begin{array}{l}\text { The use of soil } \\
\text { conservation }\end{array}$ & soil conservation knowledge \& practices & $\begin{array}{l}\text { not know, not use (0); know, not use (1); not know, use (2); know, } \\
\text { use (3) }\end{array}$ \\
\hline Land cover & canopy density & $<10 \%(0) ; 10-40 \%(1) ; 40-70 \%(2) ;>70 \%(3)$ \\
\hline Diversity & biodiversity/variety of vegetation & $<3(0) ; 3-6(1) ; 6-10(2) ;>10(3)$ \\
\hline Land cultivation & $\begin{array}{l}\text { land cultivation area compare to minimum } \\
\text { area to proper life (MAPL) }\end{array}$ & no land (0); <MAPL (1); = MAPL (2); >MAPL (3) \\
\hline \multicolumn{3}{|l|}{ ECONOMIC } \\
\hline Sum of product & $\begin{array}{l}\text { sum of product derived from agroforestry } \\
\text { system }\end{array}$ & $<3(0) ; 3-6(1) ; 6-10(2) ;>10(3)$ \\
\hline Product market & marketing pattern & $\begin{array}{l}\text { subsistent/ no sell (0); subsistent-seller(1); seller(2); wholesaler' } \\
\text { public market (3) }\end{array}$ \\
\hline $\begin{array}{l}\text { AF income } \\
\text { contribution }\end{array}$ & $\begin{array}{l}\text { agroforestry income contribution to total } \\
\text { income in percentage }\end{array}$ & $<25 \%(0) ; 25-50 \%(1) ; 50-75 \%(2) ;>75 \%(3)$ \\
\hline $\begin{array}{l}\text { Non-AF income } \\
\text { contribution }\end{array}$ & $\begin{array}{l}\text { non-agroforestry income contribution to total } \\
\text { income in percentage }\end{array}$ & $<25 \%(0) ; 25-50 \%(1) ; 50-75 \%(2) ;>75 \%(3)$ \\
\hline Poverty level & $\begin{array}{l}\text { individual/ farmer poverty rate compare to } \\
\text { poverty rate(PR) in district level }\end{array}$ & $<\mathrm{PR}(1) ;=\mathrm{PR}(2) ;>\mathrm{PR}(3)$ \\
\hline $\begin{array}{l}\text { Family member } \\
\text { defendants }\end{array}$ & $\begin{array}{l}\text { number of family member (excep head of } \\
\text { family) }\end{array}$ & $>7(0) ; 5-7(1) ; 3-5(2) ; 1-3(3)$ \\
\hline $\begin{array}{l}\text { Adaptation on } \\
\text { demand }\end{array}$ & $\begin{array}{l}\text { presence of effort to fulfill a demand of } \\
\text { agroforestry products }\end{array}$ & none (1); yes, no effort (2); yes, with effort (3) \\
\hline \multicolumn{3}{|l|}{ SOCIAL } \\
\hline Educational level & educational level of farmer & $\begin{array}{l}\text { none (0); under junior high school (2); senior high school (3); college } \\
(3)\end{array}$ \\
\hline $\begin{array}{l}\text { Perception on soil } \\
\text { conservation }\end{array}$ & perception on benefit of soil conservation & no benefit ( 0$)$; less benefit (1); moderate benefit (2); good benefit \\
\hline $\begin{array}{l}\text { Perception on } \\
\text { agroforestry } \\
\text { activity }\end{array}$ & perception on agroforestry activity & poor (1); moderate (2); good (3) \\
\hline $\begin{array}{l}\text { Participation on } \\
\text { agroforestry } \\
\text { activity }\end{array}$ & $\begin{array}{l}\text { frequency of individual participation on } \\
\text { agroforestry activity }\end{array}$ & never (1); sometimes (2); always (3) \\
\hline \multicolumn{3}{|l|}{ INSTITUTIONAL } \\
\hline $\begin{array}{l}\text { Farmer group } \\
\text { activities }\end{array}$ & farmer group activities in a year & None $(0) ; 1-2(1) ; 3-4(2) ;>4(3)$ \\
\hline $\begin{array}{l}\text { Knowledge on } \\
\text { traditional rules }\end{array}$ & $\begin{array}{l}\text { knowledge } \& \text { implementation of traditional } \\
\text { rules }\end{array}$ & $\begin{array}{l}\text { not know (0); know, not implemented (1); not know, implemented } \\
\text { (2); know, implemented (3) }\end{array}$ \\
\hline $\begin{array}{l}\text { Decision making } \\
\text { of farmer group }\end{array}$ & $\begin{array}{l}\text { Actor who make a decision in farmer group } \\
\text { activity }\end{array}$ & $\begin{array}{l}\text { Not know (0); government/ facilitator (1); head/ caretaker (2); } \\
\text { member (3) }\end{array}$ \\
\hline $\begin{array}{l}\text { Leadership on } \\
\text { farmer groups }\end{array}$ & leadership on farmer groups & poor $(1) ;$ moderate $(2) ; \operatorname{good}(3)$ \\
\hline \multicolumn{3}{|l|}{ TECHNOLOGY } \\
\hline Land preparation & land preparation types & Burnt $(0)$; clear cutting $(1)$; fertilized $(2)$; clear cut \& fertilized \\
\hline Planting & planting types & $\begin{array}{l}\text { Local seed planting (1); good quality seed planting (2); good quality } \\
\text { seed planting with distance arrangement (3) }\end{array}$ \\
\hline Plant maintenance & frequency of plant maintenance & $\begin{array}{l}\text { None }(0) ; 1 \text { maintenance }(1) ; 2-4 \text { maintenances }(2) ;>4 \text { maintenances } \\
\text { (3) }\end{array}$ \\
\hline Harvesting & harvesting types & $\begin{array}{l}\text { None (0); harvesting by wholes aler (1); self-harvesting ( } 2 \text { ) self- } \\
\text { harvesting with arrangement ( } 3 \text { ) }\end{array}$ \\
\hline $\begin{array}{l}\text { Post-harvest } \\
\text { process }\end{array}$ & post-harvest process types & $\begin{array}{l}\text { None ( } 0) \text {; raw product (1); processed in some product (2); processed } \\
\text { in other product ( } 3)\end{array}$ \\
\hline $\begin{array}{l}\text { Type of soil } \\
\text { conservation }\end{array}$ & $\begin{array}{l}\text { type of soil conservation of agroforestry } \\
\text { farmer }\end{array}$ & $\begin{array}{l}\text { None ( } 0) \text {; vegetative conservation (1); civil technique conservation } \\
(2) \text {; vegetative and civil conservation (3) }\end{array}$ \\
\hline
\end{tabular}




\section{References}

1. Arifin H S, Sardjono M A, Sundawati L, Djogo T, Adolf G, Wattimena dan Widianto 2003 Agroforestri di Indonesia. Bahan Latihan. World Agroforestry Centre (ICRAF) Bogor

2. BPS 2020 NTT dalam Angka 2020 BPS NTT Kupang

3. Pemprov NTT, DKP, WFP Pemerintah Provinsi Nusa Tenggara Timur, Dewan Ketahanan Pangan, dan World Food Programme 2015 Peta Ketahanan dan Kerentanan Pangan Provinsi Nusa Tenggara Timur 2015. Jakarta: Pemerintah Provinsi Nusa Tenggara Timur, Dewan Ketahanan Pangan, dan World Food Programme

4. Sardjono M A, Djogo T, Arifin H S dan Wijayanto 2003 Klasifikasi dan Pola Kombinasi Komponen Agroforestry. Bahan Ajaran Agroforestri 2. World Agroforestry Centre (ICRAF) Bogor

5. Njurumana GN 2006 Pendekatan Rehabilitasi Lahan Kritis Mela lui Pengembangan Mamar (Studi Kasus Mamar di Kabupaten TTS). Prosiding Sosialisasi Hasil Hasil Penelitian dan pengembangan Kehutanan. Pusat Penelitian dan Pengembangan Hutan dan Konservasi Alam Kupang

6. Njurumana G N, Victorino B A dan Pratiwi 2008 Potensi Pengembangan Mamar Sebagai Model Hutan Rakyat Dalam Rehabilitasi Lahan Kritis di Timor Barat. Jurnal Penelitian Hutan dan Konservasi Alam Vol. V No. 5 Tahun 2008. Pusat Penelitian dan Pengembangan Hutan dan Konservasi Alam. Bogor

7. Njurumana G N dan Susila I W 2006 Kajian Rehabilitasi Lahan Kritis Melalui Pengembangan Hutan Rakyat Berbasis Sistem Kaliwu di Pulau Sumba.Jurnal Penelitian Hutan dan Konservasi Alam Volume III Nomor 1 Tahun 2006 Pusat Penelitian dan Pengembangan Hutan dan Konservasi Alam. Bogor

8. Pujiono E, Raharjo S A S, Njurumana GN, Pra setyo B D dan Rianawati H 2013 Kajian Aspek Ekologi, Ekonomi Dan Sosial Model-Model Agroforestri di Nusa Tenggara Timur Prosiding Seminar Nasional Agroforestri 2013 , Kerjasama BalaiPenelitian Teknologi Agroforestri (BPTA) Ciamis - ICRAF - Unibraw Malang,

9. Nair P K R, Toth G G 2016 Measuring a gricultural sustainability in a groforestry systems. In: Lal R, Kraybill D, Hansen DO, Singh BR, Mosogoya T, Eik LO (eds) Climate change and multi dimensional sustainability in African agriculture vol 18. Springer InternationalPublishing, Cham, pp 365-394

10. Montagnini F and Metzel R 2017 The Contribution of Agroforestry to Sustainable Development Goal 2: End Hunger, Achieve Food Security and Improved Nutrition, and Promote Sustainable Agriculture." Integrating Landscapes: Agroforestry for Biodiversity Conservation and Food Sovereignty. Ed. F. Montagnini. Cham, Switzerland: Springer InternationalPublishing, 2017.

11. Njurumana GN, Marsono J, Irham dan Sa dono R 2017 Inisia tif Lokal Pengembangan Ekosistem Unggul Berba sis Masyarakat, Implikasi Produksi, Pelestarian dan Kesejahteraan. Prosiding Seminar Naional Ekosistem Unggul UGM Yogyakarta

12. Pitcher T J and Preiskhot D 2001 'RAPFISH: A Rapid Appraisal Technique to Evaluate the Sustainability Status of Fisheries'. Fisheries Research. 200149 pp. 255-270

13. Sukwika T, Darusman D, Kusmana C and Nurrohmat DR 2016 Evaluating the level of Susta inability of priva tely managed forest in Bogor, Indonesia. Biodiversitas Vol 17 Number 1 pages 241-248

14. Widiatmaka, Munibah K dan Sitorus M R P 2015 Appraisal Keberlanjutan Penggunaan Lahan untuk Sawah di Karawang- Jawa Barat. Kawistara Vol. 5 No. 2 Hal: 113-131

15. Nandini R, KusumandariA, Gunawan T and Sadono R 2017 'Multidimensional scaling approach to evluate the level of community forestry sustainability in Babak Watershed, Lombok Island, West Nusa Tenggara '.Forum Geografi. 201731 (7) pp. 28-42

16. Kavanagh P and Pitcher T 2004 Implementing Microsoft Excel Software For Rapfish: A Technique for The Rapid Appraisal of Fisheries Status. Fisheries Centre Research Report 12(2) (Canada: University of British Colombia) 